\title{
Risk Factors For Diabetic Polyneuropathy
}

\section{Diyabetik Polinöropati için Risk Faktörleri}

\author{
Yüksel KAPLAN ${ }^{1}$, Semiha KURT ${ }^{2}$, Hatice KARAER ÜNALDI ${ }^{2}$, Ünal ERKORKMAZ ${ }^{3}$ \\ 'Department of Neurology, Inönü University Faculty of Medicine, Turgut Özal Medical Center, Malatya, Turkey \\ 2Department of Neurology, Gaziosmanpaşa University Faculty of Medicine, Tokat, Turkey \\ ${ }^{3}$ Department of Biostatistics, Gaziosmanpaşa University Faculty of Medicine, Tokat, Turkey
}

\section{ABSTRACT}

Introduction: The aim of this study was to investigate the risk factors for distal symmetric sensory-motor polyneuropathy (DSP) in patients with type 2 diabetes mellitus (DM).

Method: Sixty seven patients with type 2 DM (33 males and 34 females) were included in the study. In addition to a detailed neurological examination, the Michigan Neuropathy Screening Instrument was administered to all patients and their total neuropathy scores were calculated. Nerve conduction examinations were performed for all patients.

Results: The mean age of the patients was $52.83 \pm .87$ years. The mean glycosylated hemoglobin $(\mathrm{HbA} 1 \mathrm{C}$ ) value was $8.56 \pm 2.07 \%$ (normal: $3-6.5 \%$ ). The total neuropathy score significantly correlated with diabetes duration, hypertension, retinopathy, and $\mathrm{HbA} 1 \mathrm{C}$.

Conclusion: This study confirms the previous reports regarding the association of neuropathy with poor glycaemic control and duration of the disease. The association of neuropathy with retinopathy and hypertension is important. (Archives of Neuropsychiatry 2014; 51: 11-14)

Key words: Type 2 diabetes mellitus, peripheric neuropathy, risk factors

Conflict of Interest: The authors reported no conflict of interest related to this article.

\section{Introduction}

Diabetes mellitus (DM) is one of the most common diseases encountered in the community. D,stal symmetrical sensori-motor polyneuropathy (DSP) is the most common syndrome among diabetic neurpathies (1). Investigation and appropraite treatment of this problem are important because of its effect on qualityof life and related anxiety and depression (2).

In prospective and cross-sectional studies, some risk factors for DSP have been defined. The most important ones among these factors include $\mathrm{HbA} 1 \mathrm{c}$ level which reflects poor diabetic control, diabetes duration and demographic parameters including age, height and male gender $(3,4,5,6)$. Some studies have shown that risk factors for atherosclerosis including
ÖZET

Amaç: Bu çalışmada tip 2 diyabetes mellituslu (DM) hastalarda distal simetrik sensori-motor polinöropati (DSP) için risk faktörlerinin araştırılması amaçlanmıştır.

Yöntem: Tip 2 DM olan 34'ü kadın, 33'ü erkek olmak üzere 67 hasta çalışmaya alındı. Hastaların ayrıntılı nörolojik muayeneleri yapılıp, Michigan Nöropati Değerlendirme Ölçeği'nin Nöropati Tarama Anketi uygulandı ve total nöropati skorları hesaplandı. Polinöropati protokolüne uygun olarak sinir iletim çalışmaları yapıldı.

Sonuç: Hastalar 32-77 yaş arasındaydı ve yaş ortalamaları 54,57 $\pm 8,64$ idi. Ortalama glikolize hemoglobin (HbA1C) değerleri \%8,32+1,81 (normal: \%3-6,5) idi. Total nöropati skoru, diyabet süresi, nöropatik semptom süresi, hipertansiyon, retinopati ve $\mathrm{HbA} 1 \mathrm{C}$ değerleri arasında istatistiksel olarak anlamlı ilişki saptandı. (Archives of Neuropsychiatry 2014; 51: 11-14)

Anahtar kelimeler: Tip 2 diyabetes mellitus, periferik nöropati, risk faktörleri

Çıkar Çatışması: Yazarlar bu makale ile ilgili olarak herhangi bir çıkar çatışması bildirmemişlerdir.

Some of the cases presented in this study were presented as poster presentations at the $13^{\text {th }}$ European Congress of Clinical Neurophysiology (Istanbul, 2008). 
diagnosis of type $2 \mathrm{DM}$ was made according to the criteria of the American Diabetes Association (10).

Detailed opthalmological, physical and neurological examination was performed in all patients. Interrogation for neuropathy was made in all patients using the Neuropathy Screening Questionnaire of the Michigan Neuropathy Assessment Scale (11) which was developed by Feldman and Stevans and which is also used in our country. Additionally, the total neuropathy scores developed by Cornblath et al. (12) were calculated (12). The patients with a total neuropathy score of 3 and higher were evaluated as polyneuropathy.

The age, gender, diabetes duration, duration of neuropathic symptoms, antidiabetic therapy used, presence of retinopathy, hypertension and hyperlipidemia, history of smoking and mean glycated hemoglobin ( $\mathrm{HbA1C}$ ) levels of the patients were recorded. The patients who had other morbidities leading to neuropathy including uremia, malnutrition, hepatic failure, alcoholism and vitamin deficiency were not included in the study. In addition, the patients who had a history of type $1 \mathrm{DM}$ and who used drugs which could lead to neuropathy were not included in the study.

Nerve conduction studies were performed using Medelec-0xford Synergy EMG device with $20 \mathrm{~Hz}-10 \mathrm{kHz}$ filter setting and $50 \mathrm{~ms}$ analysis time. All recordings were made using superficial electrodes and the extremity temperature was kept above 31 degrees. In accordance with the polyneuropathy protocol defined by $\mathrm{Oh}$ median motor and sensory (finger-wrist, wrist-elbow) examination was performed in one upper extremity, posterior tibial and peroneal nerve motor conduction study was performed in one lower extremity and sural nerve conduction studies were performed bilaterally (13). Decelleration or failure to obtain action potential or low-amplitude action potential in at least two nerves was defined as polyneuropathy.

The study was performed in accordance with the Helsinki Deceleration and informed consent was obtained from all patients after giving detailed information about the study.

Independent two sample t test was used for comparison of the continuous data used in the study between the groups. The continuous data were shown by way of arithmetic mean and standard deviation. Chi-square test was used for comparison of the categorical variables between the groups. The categorical variables were expressed as numbers and percentages. Pearson and Spearman correlation analyses were used to evaluate the factors related with the total neuropathy number and $\mathrm{p}$ values below 0.05 were considered statistically significant. The calculations were made by SPSS 19 statistical software (IBM SPSS Statistics 19, SPSS inc., an IBM Co., Somers, NY, USA).

\section{Results}

The patients were aged between 32 and 77 years and the mean age was $54.57 \pm 8.64$ years. The mean diabetes duration was found to be $9.07 \pm 5.44$ and the diabetes durations ranged between 1 and 25 years. The mean age of the female patients was statistically significantly lower compared to the male patients, whereas the $\mathrm{HbA1C}$ values of the female patients were statistically significantly higher. No statistically significantly difference was found between the female and male patients in terms of diabetes duration, neuropathic symptom duration, neuropathic questioning scores and total neuroapthy scores (Table 1).

While 2 of the diabetic patients were not receiving any therapy, 41 were receiving oral antidiabetics (OAD), 17 were receiving insulin and 7 were receiving both $O A D$ and insulin. While polyneuropathy was not found in 40 patients, 27 patients had polyneuropathy. In addition, 21 patients had retinpathy, 44 patients had hypertension, 43 patients had hyperlipidemia and 15 patients had a history of smoking.

A statistically significantly correlation was found between the total neuropathy score and diabetes duration, retinopathy, hypertension and $\mathrm{HbA} 1 \mathrm{c}$ levels. No significant correlation was found between the other factors investigated (age, gender, height, therapy, hyperlipidemia, smoking) (Table 2). Only diabetes duration and neuropathic symptom duration were found to be statistically significantly correlated with the Neuropathy Screening Questionnaire score (Table 2).

Table 1. Clinical findings and $\mathrm{HbA1c}$ values of the patients

\begin{tabular}{|lccccccc|}
\hline & Minimum & Maximum & Total & $\begin{array}{c}\text { Female patients } \\
\mathbf{n}=34\end{array}$ & $\begin{array}{c}\text { Male patient } \\
\text { s n=33 }\end{array}$ & p \\
\hline Age (years) & 32 & 77 & $54.57 \pm 8.64$ & $51.85 \pm 7.75$ & $57.36 \pm 7.75$ & .008 \\
Height (meters) & 1.50 & 1.80 & $1.63 \pm 0.09$ & $1.56 \pm .05$ & $1.71 \pm .05$ & .0001 \\
Diabetes duration (years) & 1.00 & 25.00 & $9.07 \pm 5.44$ & $9.22 \pm 5$ & $8.91 \pm 5.92$ & .817 \\
Neuropathic symptom duration (years) & .20 & 18.00 & $3.89 \pm 3.94$ & $3.78 \pm 4.36$ & $4 \pm 3.49$ & .847 \\
Neuropathic questioning score & 0 & 14 & $4.73 \pm 1.81$ & $4.15 \pm 2.63$ & $5.33 \pm 3.73$ & .136 \\
Total neuropathy score & 0 & 20 & $5.2 \pm 3.25$ & $5.12 \pm 4.82$ & $5.45 \pm 5.38$ & .788 \\
HbA1c & 5.70 & 14.00 & $8.32 \pm 1.81$ & $8.78 \pm 2.12$ & $7.84 \pm 1.30$ & .034 \\
\hline The data are given as mean \pm standard deviation & & & & & & & \\
\hline
\end{tabular}


Table 2. The correlation of the total neuropathy score and neuropathic interrogation score with clinical properties of diabetic patients

\begin{tabular}{|lcccc|}
\hline & \multicolumn{2}{c|}{ Total neuropathy score } & \multicolumn{2}{c|}{ Neuropathic interrogation score } \\
\hline Age (years) & $\mathbf{r}$ & $\mathbf{p}$ & $\mathbf{r}$ & $\mathbf{p}$ \\
Gender & .231 & .061 & .069 & .581 \\
Height & .039 & .755 & -.12 & .334 \\
Diabetes duration & .069 & .597 & .158 & .219 \\
Retinopathy & .524 & .0001 & .313 & .01 \\
Hypertension & .430 & .0001 & .096 & .456 \\
Hyperlipidemia & .272 & .026 & -.06 & .632 \\
History of smoking & .217 & .081 & -.085 & .498 \\
HbA1c & -.096 & .440 & -.057 & .647 \\
\hline
\end{tabular}

\section{Discussion}

The most accurate diagnosis of DSP is made with association of neuropathic symptoms, findings and abnormal electrophysiological findings (14). In this study, the total neuropathy score which covers these three parameters was used.

In our study, a significant correlation was found between the total neuropathy score and diabetes duration, neuropathic symptom duration, retinopathy, hypertension and poor diabetes control, while no correlation was found between the total neuropathy score and age, gender, height, therapy and hyperlipidemia and smoking which are among the atherosclerotic risk factors. A statistically significant correlation was found between retinopathy and the total neuropathy score. The correlation between retinopathy and neuropathy is a significant and expected result because both reflect the disease duration and severity of hyperglycemia.

Height was defined as a risk factor in previous studies, because longer neurons carry a higher risk in terms of metabolic and/or ischemic damage and thus may be an indication of neuronal length (7). However, no correlation was found between the total neuropathy score and height. In the study of Barbosa et al. (8), no correlation was found between height and polyneuropathy similar to our study (8). This may have arised from the fact that height is not a direct indicator of neuronal length.

No significant correlation was found between gender and the total neuropathy score in this study. Tamer et al. (9) and Booya et al. (15) reported that neuropathy was more common in male diabetic patients $(9,15)$. However, Barbosa et al. and Perkins et al. reported that no difference was present between genders in terms of DSP similar to our study $(8,16)$. In contrast to the literature, no correlation was found between age and the total neuropathy score.

In our study, the risk factor which was correlated with both the total neuropathy score and Neuropathy Screening Questionnaire scores was diabetes duration. This confirms that diabetes duration is a significant and unchangeable risk factor. In addition, impaired nerve conductions were found even in early diabetics with good control who had no clinical and Standard electrophysiological findings compared to non-diabetic individuals and it was demonstrated that diabetic neuropathy may begin in a very early period (17).

We think that differences of risk factors for DSP in the literature may be related with the fact that some of the studies were based on only clinical findings and the ones which also included electrophysiological findings used different parameters including amplitude and nerve conduction rate. We think that determining risk factors for DSP is valuable in terms of prevention or impediment of neuropathy by intervening especially in changeable factors in the early stage.

\section{References}

1. Ertekin C. Diyabetik nöropatiler. Ertekin C, editör. Sentral ve periferik EMG içinde. 1. Baskı. Izmir: Meta Basım; 2006; s.212-213.

2. Vileikyte L, Leventhal H, Gonzalez JS, Peyrot M, Rubin RR, Ulbrecht JS, Garrow A, Waterman C, Cavanagh PR, Boulton AJ. Diabetic peripheral neuropathy and depressive symptoms: the association revisited. Diabetes Care 2005; 28:2378-2383.

3. Maser R, Steenkiste A, Dorman J, Nielsen V, Bass E, Manjoo O, Drash AL, Becker DJ, Kuller LH, Greene DA. Epidemiological correlates of diabetic neuropathy: report from Pittsburgh Epidemiology of Diabetes Complications Study. Diabetes 1989; 38:1456-1461.

4. Tesfaye S, Stevens L, Stephenson J, Fuller J, Plater M, IonescuTirgoviste C, Nuber A, Pozz G, Ward JD. Prevalence of diabetic peripheral neuropathy and its relation to glycaemic control and potential risk factors: the EURODIAB Type I Complications Study. Diabetologia 1996; 39:1377-1384.

5. Forrest K, Maser R, Pambianco G, Becker D, Orchard T. Hypertension as a risk factor for diabetic neuropathy: a prospective study. Diabetes 1997; 46:665-670.

6. Adler Al, Boyko EJ, Ahroni JH, Stensel V, Forsberg RC, Smith DG. Risk factors for diabetic peripheral sensory neuropathy. Results of the Seattle Prospective Diabetic Foot Study. Diabetes Care 1997; 20:1162-1167. 
7. Tkac I, Bril V: Glycemic control is related to the electrophysiologic severity of diabetic peripheral sensorimotor polyneuropathy. Diabetes Care 1998; 21:1749-1752.

8. Barbosa AP, Medina JL, Ramos EP, Barros HP, The DPN in Porto Study Group. Prevalence and risk factors of clinical diabetic polyneuropathy in a Portuguese primary health care population. Diabetes Metab 2001; 27:496-502.

9. Tamer A, Yıldız S, Yıldız N, Kanat M, Gunduz H, Tahtacı M, Celebi $H$. The prevalence of neuropathy and relationship with risk factors in diabetic patients: a single-center experience. Med Princ Pract. 2006; 15:190-194.

10. American Diabetes Association. Position statement: standards of medical care for patients with diabetes mellitus. Diabetes Care 2002; 25:33-49.

11. Feldman EL, Stevens MJ. Clinical testing in diabetic peripheral neuropathy. Can J Neurol Sci 1994; 21:3-7.

12. Cornblath DR, Chaudhry V, Carter K, , Lee D, Seysedadr M, Miernicki $\mathrm{M}$, Joh T. Total neuropathy score: validation and reliability study. Neurology 1999; 53:1660-1664.

13. Oh S. Anatomical guide for common nerve conduction studies. Oh Shin MD, editör. Clinical Electromyography: Nerve Conduction Studies içinde. 1. Baskı. Baltimore: Park Press; 1984; s. 65-85.
14. England JD, Gronseth GS, Franklin, Miller RG, Asbury AK, Carter GT, Cohen JA, Fisher MA, Howard JF, Kinsella LJ, Latov N, Lewis RA, Low PA, Sumner AJ; American Academy of Neurology; American Association of Electrodiagnostic Medicine; American Academy of Physical Medicine and Rehabilitation. Distal symmetric polyneuropathy: a definition for clinical research: report of the American Academy of Neurology, the American Association of Electrodiagnostic Medicine, and the American Academy of Physical Medicine and Rehabilitation. Neurology 2005; 64:199-207.

15. Booya F, Bandarian, Larijani B, Pajouhi M, Nooraei M, Lotfi J. Potential risk factors for diabetic neuropathy: a case control study. BMC Neurology 2005; 5:24:1-5.

16. Perkins BA, Greene DA, Bril V. Glycemic control is related to the morphological severity of diabetic sensorimotor polyneuropathy. Diabetes Care 2001; 24:748-752.

17. Dikmen-Yalınay $P$, Ünlüsoy Acar S, Dinçağ N, Öğe E. Submaksimal uyarımla elde edilen iki tepeli ortodromik duysal yanıtların hastalık süreçlerine yönelik elektrofizyolojik incelemelerde kullanılması. Nöropsikiyatri Arşivi 2010; 47:338-343. 